\title{
Hotspots of biodiversity and ecosystem services: the Outermost Regions and Overseas Countries and Territories of the European Union
}

\author{
Ina Maren Sieber ${ }^{\ddagger}$, Paulo AV Borges $\$$, Benjamin Burkhard ${ }^{\ddagger}$, \\ ‡ Leibniz Universität Hannover, Institute of Physical Geography and Landscape Ecology, Hannover, Germany \\ $\S C E 3 C$ - Centre for Ecology, Evolution and Environmental Changes / Azorean Biodiversity Group and Universidade dos \\ Açores, Dep. de Ciências e Engenharia do Ambiente, Angra do Heroísmo, Açores, Portugal \\ | Leibniz Centre for Agricultural Landscape Research ZALF, Müncheberg, Germany
}

Corresponding author: Ina Maren Sieber (sieber@phygeo.uni-hannover.de)

Academic editor: Evangelia Drakou

Received: 27 Feb 2018 | Accepted: 06 Jun 2018 | Published: 12 Jun 2018

Citation: Sieber I, Borges P, Burkhard B (2018) Hotspots of biodiversity and ecosystem services: the Outermost

Regions and Overseas Countries and Territories of the European Union. One Ecosystem 3: e24719.

https://doi.org/10.3897/oneeco.3.e24719

\begin{abstract}
The obligations of the EU Biodiversity Strategy 2020 create a need for mapping and assessment of the state of biodiversity, ecosystems and their services in all European member states. Europe's nine Outermost Regions (ORs) and 25 Overseas Countries and Territories (OCTs) are mainly islands, scattered around the globe. These territories contain unique flora and fauna and encompass diverse ecosystems, from coral reefs to rainforests. These highly diverse ecosystems provide multiple relevant ecosystem services from local to global scale. To date, the ecosystem services concept has so far received little attention in European ORs and OCTs. Therefore, our aims were (1) to analyse the current state of ecosystem services mapping and assessment in Europe's overseas territories, (2) to identify knowledge gaps in the context of ecosystem service research and application and (3) to provide recommendations for future research and policy directions to fill these gaps. We conducted a systematic review of scientific literature for each of the ORs and OCTs, screening 1030 publications. The analysis resulted in 161 publications referring to ES mapping and assessment, of which most were conducted in the European Caribbean $(31 \%)$ and Pacific (21\%) territories. Results show that many ORs and OCTs are still blank
\end{abstract}


spots in terms of ecosystem service mapping and assessment and that, despite many biodiversity studies referring to species' abundance, little has been published on ecosystem services. Our systematic review highlights theknowledge lacking on dealing with invasive species, which pose major threats to native island biodiversity, ecosystem functions and ecosystem services. Further, it discusses knowledge gaps in (1) translation of information on island biodiversity and ecosystem functions into ES; (2) geographical coverage of mapping studies in most ORs and OCTs; (3) the lack of standardised approaches and integrated assessments to map, assess and value ecosystem services. Based on these results, future research and policy priorities could be adapted in order to focus on filling these gaps. To overcome current environmental policy challenges, it is crucial to address the ongoing decline in biodiversity, rising climatic and anthropogenic pressures on ecosystems and to maintain a sustainable ES flow to safeguard human well-being. Ultimately, ES mapping and assessment efforts will form the knowledge base for wellinformed decision-making to protect Europe's vulnerable overseas areas.

\section{Keywords}

Mapping and Assessment of Ecosystems and their Services, European Union, invasive species, review study

\section{Introduction}

Mapping and Assessment of Ecosystems and their Services (MAES) have received growing attention within the European scientific, policy and practitioner communities to safeguard biodiversity and sustain land use management (Maes et al. 2013, Maes et al. 2016). The work of the European Commission's MAES Working Group*1 contributes to the EU Biodiversity Strategy to 2020, which foresees in Target 2, Action 5 that all member states shall "map and assess the state of ecosystems and their services in their national territory by 2014, assess the economic value of such services, and promote the integration of these values into accounting and reporting systems at EU and national level by 2020" (European Commission 2011, p.12). In line with the Millennium Ecosystem Assessment (Millennium Ecosystem Assessment 2005), MAES aims to provide a critical evaluation of information available to guide decision-making on natural resources management and achieve no net loss of species and biodiversity on EU territories. Ultimately, such assessments of ecosystems and their services can address a broad range of policyrelevant questions, for example on key drivers causing change to ecosystems and ecosystem services (ES) or how to address degradation of ecosystems and biodiversity loss (Maes et al. 2013, Bouwma et al. 2018). In this study, we differentiate between the MAES implementation process, which refers to the concrete EU-guided process of implementation of Action 5 in EU member states under the framework of the EU Biodiversity Strategy and the terms "ES mapping and assessment". The latter refers to the processes, methods and data collection taking place to create maps of ecosystems and ES and/or to value and assess ecosystems and their services. The outcomes are usually 
spatially explicit maps of ES supply or demand, which are a very important tool for bringing ES into practical application (Burkhard and Maes 2017).

Extensive mapping and assessment efforts can be seen on the European mainland (e.g. EU-initiated initiatives and projects such as MAES, ESMERALDA*2 and CICES*3). A growing number of studies and approaches has been published on the topic of ES mapping (Crossman et al. 2012, Burkhard and Maes 2017). Although following different conceptual frameworks, most mapping studies have started to distinguish between ES potential (or capacity), flow and demand (Syrbe et al. 2017, Burkhard et al. 2012, Villamagna et al. 2013), as well as benefits (Bastian et al. 2012). Comprehensive national ecosystem assessments have already been provided by various EU member states such as the United Kingdom (UK NEA 2011), Spain (Santos-Martín et al. 2016), the Netherlands (De Knegt 2014), France (Ministère de l'Environnement, de l'Énergie, et de la Mer 2015) and Portugal (Pereira et al. 2009) (see also Schröter et al. 2016). The latter includes ecosystem assessment profiles with scenario building available for the EU outermost region of the Azores (Borges et al. 2009).

Europe's Outermost Regions (ORs) and Overseas Countries and Territories (OCTs) often seem to be overlooked in MAES efforts. ORs are territories located at distance from continental Europe but make up substantial parts of EU Member State's territories. ORs include the Azores, Madeira, Canary Islands and the French Overseas departments of French Guiana, Guadeloupe, Martinique, Saint Martin, La Réunion and Mayotte. OCTs are territories that have a special bond with EU Member States of either France, United Kingdom, Denmark or the Netherlands. These 25 territories are associated by EU law rather than by constitutional law of an EU Member State (Kochenov 2013). According to the 'Treaty on the Functioning of the European Union', ORs and some OCTs comply with primary and secondary European Union Law. Derogation rules are based on differing legal status and the "structural social and economic situation [...] which is compounded by their remoteness, insularity, small size, difficult topography and climate [etc.]" (EU 2016, p. 195).

The EU overseas areas are rich in biodiversity and natural resources, ranging from polar seas in Greenland, wetlands, coral reefs and volcanic islands to tropical forests (Petit and Prudent 2008). In total, these areas host more than $70 \%$ of all EU biodiversity and include $20 \%$ of the world's coral reefs and lagoons (Petit and Prudent 2008). Together, these areas provide also the world's largest Exclusive Economic Zone (EEZ) of 15 million $\mathrm{km}^{2}$ with access to global key fishing grounds. Most ORs and OCTs are small island states. Therefore, they heavily rely on natural resources, such as marine and coastal ecosystems (Wong et al. 2005, Nunes et al. 2014) or montane forests (Borges et al. 2009). All these ecosystems play an important role in the protection of island biodiversity and frequently serve as 'green infrastructure'. These ecosystems are providing a variety of ES of global and regional importance (e.g. water regulation, erosion control, pollination, pest-control, food supply and recreation), which translate to a substantial but often unrecognised contribution to local island economies (Borges et al. 2009). They are furthermore providing crucial contributions to the tourism sector (Wong 1993, UNEP and PAP/RAC. 2009) and many cultural ES depend on natural diversity and healthy ecosystems (Worm et al. 2006). 
Today, ecosystems in many ORs and OCTs are threatened. Temperate, semi-tropical and tropical oceanic islands have experienced serious lowland clearance, leading to land cover and land use changes, forcing the last remnants of pre-human pristine forest to higher elevations. In addition, the complex interplay between the EU Agriculture Policies (EU mainland-driven) and land use intensification in small territories have affected native ecosystems severely (Borges et al. 2009). The introduction of invasive species has altered many ecosystems irreversibly, often with yet unknown effects (Vila and Hulme 2017). Economic activities such as overexploitation of fishing grounds (Hutchings 2000), intensive nickel or gold mining (e.g. Greenland, New Caledonia or French Guiana (Douine et al. 2017)) jeopardise the health of key ecosystems and people and are generating conflict. Natural and anthropogenic climatic changes put additional pressures on ecosystems and biodiversity (Thomas et al. 2004) as they are expected to increase risks of diseases, challenge vegetation sensitive to temperature increases, accelerate coral bleaching (Heron et al. 2016) and increase extreme weather events. Just recently, this has been demonstrated by tropical storms and hurricanes, such as hurricanes Irma and Maria on the Caribbean islands of Turks and Caicos, the British Virgin Islands or St. Martin (Unsworth et al. 2017), threatening human lives, affecting fisheries, tourism and destroying crucial coastal and marine ecosystems. Without knowledge and sufficient information on the condition of ecosystems and the services they provide, it becomes difficult to assess human dependence on functioning ecosystems and other interactions in complex adaptive social-ecological systems (Millennium Ecosystem Assessment 2005).

The EU has started to protect key ecosystem functions and services in terrestrial and marine overseas environments. In 2010, the European Parliament approved a Preparatory Action inspired by the voluntary scheme for Biodiversity and ES in Territories of European Overseas (BEST*4), initially proposed by the Message from Réunion (European Commission 2008). The BEST initiative mobilises local stakeholders to identify priority areas for action and channels funding from different sources to research and conservation projects. The development of "Essential Biodiversity Indicator Variables" is recognised by BEST as one of the priorities for the European overseas islands. Demands on islands for food, clean water, fertile soils and timber are growing but little is known about the impacts of climatic changes on the ecosystems providing these ES. During the International Conference on Biodiversity and Climate Change (IUCN 2014), a roadmap was proposed to define actions to counter biodiversity loss and climate change impacts in ORs and OCTs. In addition to the BEST programme, various projects have been set up to meet the goals of the EU Biodiversity Strategy. The NetBiome-CSA ${ }^{\star} 5$ and its predecessor, for example, have focused on strengthening research partnerships concerning biodiversity since 2010 .

Despite these efforts, a review of EU-wide databases on ES and biodiversity, such as the Biodiversity Information System for Europe*6 (BISE 2017), the Ecosystem Services Partnership (ESP) Visualization Tool`7 (Drakou et al. 2015) or Open Platform (OPPLA ${ }^{\star} 8$ ), reveals large gaps in ORs and OCTs in terms of geographical coverage of ES studies in general and MAES implementation in particular. This database-screening revealed that current efforts focus mainly on continental Europe and adjacent marine regions, leaving the EU overseas areas as blank spots. 
Therefore, this paper aims to assess the current state of knowledge on MAES in ORs and OCTs in more detail. We present a thorough literature analysis of published peer-reviewed scientific literature on the topic of MAES in EU Overseas to:

1. review past and current ES mapping and assessment efforts,

2. identify knowledge gaps in the context of ES research and application, including the role of invasive species on ES and

3. to provide recommendations to future research and policy directions to fill these gaps to contribute to ES mapping and assessment efforts in ORs and OCTs and to reach EU-wide as well as global biodiversity targets.

The paper is structured as follows: Section 2 describes the methodology used to structurally review the ES mapping and assessment efforts in Europe's Overseas. Section 3 presents the results of the literature analysis on the topic, providing the baseline for current efforts, as well as touching upon the threat of invasive species jeopardising biodiversity and conservation efforts. Section 4 discusses the results in terms of geographical coverage of MAES in ORs and OCTS. Furthermore, this section presents current knowledge gaps, such as diverging conceptual frameworks, data and the need for comparability of ES mapping and assessment efforts. This section also provides an outlook for future research and guidance for enhanced policy-making concerning MAES in ORs and OCTs. Cross-cutting conclusions are drawn in Section 5.

\section{Methodology}

Our systematic review followed the Preferred Reporting Items for Systematic reviews and Meta-Analyses (PRISMA) statement (Moher 2009). PRISMA originates from medical science and aims to enhance transparency and robustness of literature reviews. We applied rigorous, objective and transparent steps to assess the current state of knowledge. The added value of this reviewing method has been demonstrated by various recent ES studies: synthesis of the current state of knowledge by assessing different ES mapping methods (Martínez-Harms and Balvanera 2012), knowledge gaps in cultural marine ES research (Rodrigues et al. 2017) and for the assessment of marine and coastal ecosystem services (Liquete et al. 2013).

\section{Data Sources}

The sources of relevant articles for this literature study were tripartite: First, peer-reviewed scientific literature, published in English language, was screened for publications on ES in ORs and OCTs. We selected Scopus (Elsevier) and Web of Science (Thomson Reuters), the two largest scientific databases for environmental and social sciences, for our search. Second, relevant scientific literature (published in English) designed to identify the current status of ES mapping and assessment was obtained from Google Scholar, including to some extent also grey literature. However, grey literature that was not publicly available or not published in English was not included in this review. As a third source, the review 
included policy documents and empirical studies that were presented during the first MAES OR\&OCT expert workshop within the scope of the ESMERALDA EU Project in Ponta Delgada, Azores, from 28.02.-03.03.2017.

\section{Data collection and analysis}

The publications were reviewed in four steps (see Fig. 1). An initial screening of articles took place from April to July 2017 by searching the scientific databases for key words ("ecosystem services" AND "mapping") and their relevant synonyms (Table 1) for each of the ORs and OCTs individually. Publications were selected based on the search terms in title, abstract or key words, using Boolean operators. Search terms were kept broad to obtain the full range of studies addressing biodiversity, ecosystems and their services.

Table 1.

Keywords used in this systematic literature review, searching the databases Scopus, Web of Science and Google Scholar (adjusted from Crossman et al. 2013).

\begin{tabular}{|c|c|c|}
\hline $\begin{array}{l}\text { Keywords referring to ecosystem } \\
\text { services }\end{array}$ & $\begin{array}{l}\text { Keywords referring to } \\
\text { mapping }\end{array}$ & $\begin{array}{l}\text { Keywords referring to the ORs and } \\
\text { OCTs }\end{array}$ \\
\hline "ecosystem" & "mapping" & Greenland \\
\hline "ecosystem services" & "map" & Saint-Pierre and Miquelon \\
\hline "ecosystem services assessment" & "geospatial" & Azores \\
\hline "ecosystem mapping" & $\begin{array}{l}\text { "geographic information } \\
\text { system" }\end{array}$ & Madeira \\
\hline "ecosystem service map" & "GIS" & Canary Islands \\
\hline "biodiversity" & "landscape" & Bermuda \\
\hline \multirow[t]{15}{*}{ "biodiversity assessment" } & "cartography" & British Virgin Islands \\
\hline & "remote sensing" & Anguilla \\
\hline & & Saint Martin \\
\hline & & Saint Barthélemy \\
\hline & & Guadeloupe \\
\hline & & Martinique \\
\hline & & Netherlands Antilles \\
\hline & & Aruba \\
\hline & & Montserrat \\
\hline & & Cayman Islands \\
\hline & & Turks and Caicos Islands \\
\hline & & French Guiana \\
\hline & & Wallis and Futuna \\
\hline & & French Polynesia \\
\hline & & Pitcairn \\
\hline
\end{tabular}




\begin{tabular}{|l|l|}
\hline & New Caledonia \\
\hline & Ascension Island \\
\hline & Saint Helena \\
\hline & Tristan da Cunha \\
\hline & Falkland Islands (Malvinas) \\
\hline & $\begin{array}{l}\text { South Georgia and the Southern Sandwich } \\
\text { Islands }\end{array}$ \\
\hline & British Antarctic Territory (BAT) \\
\hline & Adélie Land \\
\hline & $\begin{array}{l}\text { French Southern and Antarctic Territories } \\
\text { (TAAF) }\end{array}$ \\
\hline & Scattered Islands \\
\hline & Mayotte \\
\hline & Réunion \\
\hline & British Indian Ocean Territory (BIOT) \\
\hline
\end{tabular}

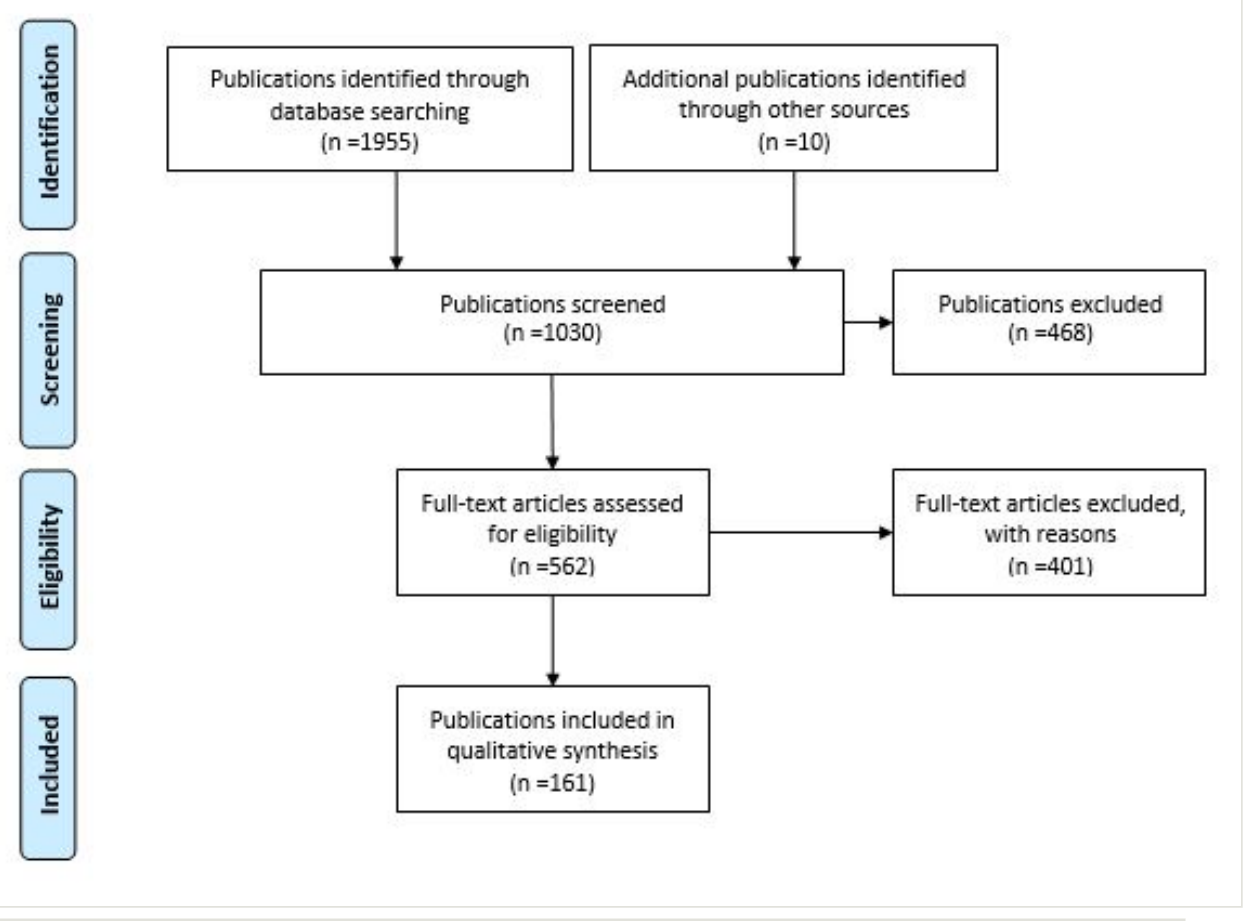

\section{Figure 1.}

Flow diagram of the methodology and selection processes used in this systematic review, following the rules and templates of PRISMA (Preferred Reporting Items for Systematic Review (Moher 2009)). 
The screening provided 1030 papers divided over the global regions of Amazonia, Macaronesia, the Caribbean, Indian Ocean, Pacific, Polar and Subpolar regions as well as the EU regions and territories in the South Atlantic (Fig. 1).

In a second step, articles were catalogued and categorised, using an adjusted version of the ES mapping and modelling blueprint (Crossman et al. 2013) and the ESMERALDA project's ES method database (Brown et al. 2018). Publications were classified according to the following characteristics:

- Year of publication

- Global and geographical region of mapping and assessment per publication

- $\quad$ Dimension of study (biophysical, social, economic, socio-economic)

- Type of Study (Mapping, assessment, review, indicator development, biodiversity, other)

- $\quad$ Spatial scale of mapping (global, multi-national, national, subnational, local, other)

- Ecosystem type considered (urban, cropland, grassland, woodland and forest, heath and shrub, sparsely vegetated, wetlands, rivers and lakes, transitional waters, coastal or marine/coral reefs)

- Information on the role of invasive species, if mentioned

- $\quad$ Ecosystem classification schemes (CICES, TEEB, MEA, not defined)

- $\quad$ Ecosystem services cascade classification per ES described

- Ecosystem service described

- Input data (GIS, remote sensing, statistical data, expert opinion, field data, literature, others)

In addition, all publications were categorised according to the ES Cascade conceptual model (Haines-Young and Potschin 2010). Afterwards, all screened papers were removed that i) were not related to EU territories, leaving a dataset of 562 publications. Further on, we removed publications that ii) focused solely on biodiversity, iii) did not mention the ES concept or iv) were descriptive in nature rather than focusing on ES mapping and assessment. This reduced the number of included papers to 161 (Suppl. material 8). As the fourth and last step, an in-depth analysis of these remaining papers was conducted, looking at the type of mapping and assessment done in the individual territories, its extent and the current shortcomings and knowledge gaps that need to be addressed in future research.

\section{Results}

The number of publications on biodiversity in ORs and OCTs has been growing exponentially (Fig. 2). The majority of the 1030 screened publications focuses on landscape structures or processes, compiling taxonomic lists, describing landscapes or individual, often endemic species (562 publications). Still, the number of publications focussing on ecosystems and their services lacks behind: only about $20 \%$ of all screened papers focus on mapping and assessment of services and benefits that ecosystems provide, leaving a total of 161 publications to be included in this review. Twenty nine 
publications (18\%) were obtained via scientific search engines and 125 publications $(78 \%)$ were found via grey literature. Only 7 publications (4\%) were provided by stakeholders or engaged projects in the regions, such as NetBiome. Whilst the search was not restricted to any time period, the obtained papers were all published between 1991 and 2017. Before 2005, publications on ES mapping and assessment in EU overseas areas were almost non-existent, with only one or two publications per year in the 1990s. A first increase was observed in 2005, when the MEA (Millennium Ecosystem Assessment 2005) was published. The second boost could be found after 2010, the year in which the EU started to invest in overseas programmes such as NetBiome and EU BEST. A peak was reached in 2016, with 22 publications.

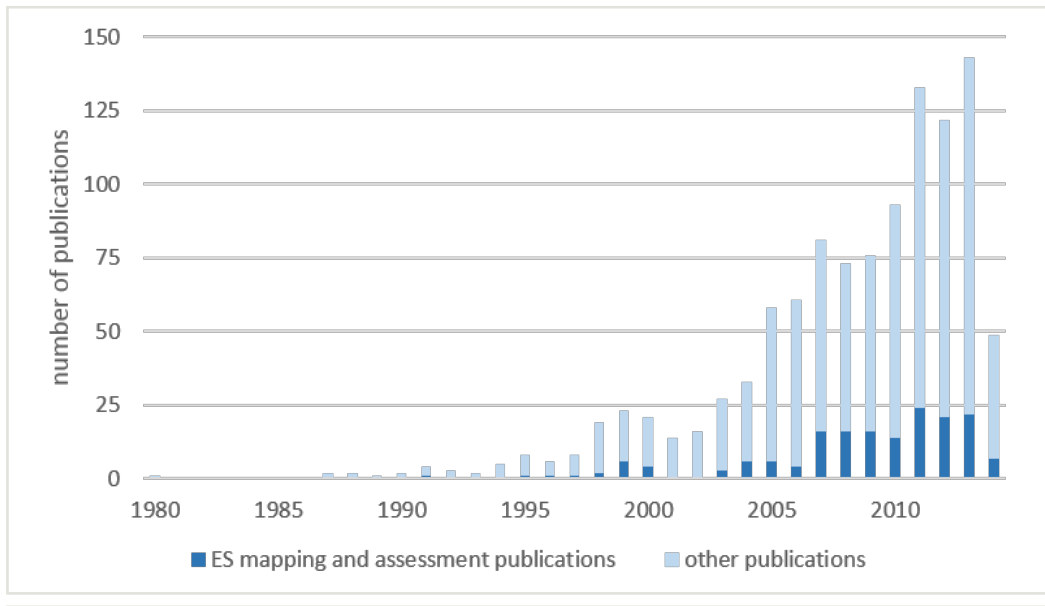

Figure 2.

Number of all screened publications in this review. (In step 4 of Fig. 1) The figure compares the number of overall publications on biodiversity and ecosystems, i.e. species richness or taxonomic lists (1030 publications screened in Scopus, Web of Science and Google Scholar) and the number of publications on mapping and assessing ecosystems and their services $(n=161)$ in all EU ORs and OCTs between 1980 and 2017.

\section{Geographical Distribution}

The 161 ES mapping and assessment publications were spread over all 7 regions (Fig. 3). Twenty five (25) out of the 34 ORs and OCTs were represented in the publications. Some publications both mapped and assessed ES in multiple regions, thus were counted for each OR and OCT separately. Sixty 60 publications covered the 14 EU-related islands in the Caribbean region (31\%). The European territories in the Pacific were covered by 39 publications (21\%). Macaronesia and the Indian Ocean were covered by a total of 29 and 32 studies each, followed by the four territories in the South Atlantic (12 publications). The eight polar- and subpolar territories were following with 10 publications, of which 8 cover ES and 2 ES benefits or valuation studies. Amazonia, with French Guiana as only country in this region, was least represented with 7 ES mapping and assessment publications, of which 4 focussed on mapping ES and 3 studies handled benefits or monetary 
assessments. This trend of ES studies outnumbering benefit studies could be observed for all regions (regional overviews can be found in the Suppl. materials 1, 2, 3, 4, 5, 6, 7).

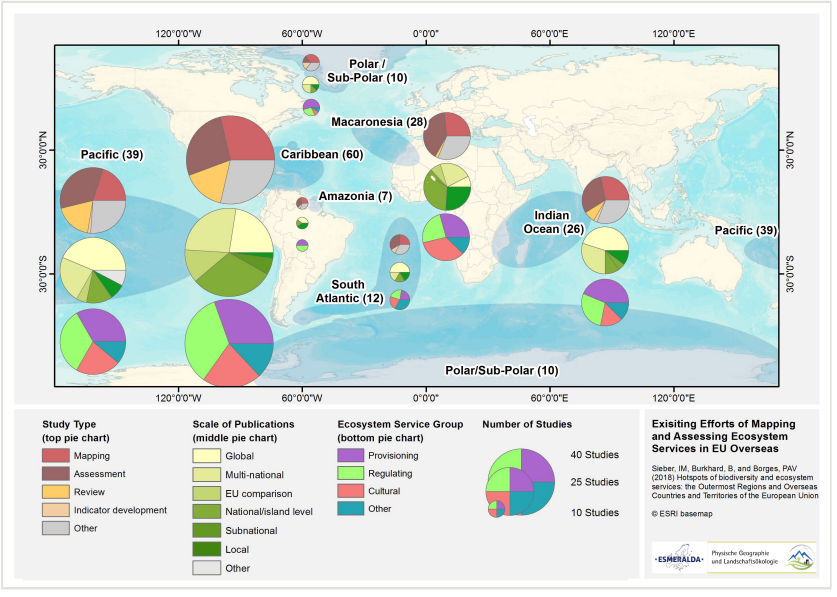

Figure 3.

Geographical location of ES mapping and assessment studies in ORs and OCTs. All publications ( $n=161$ ) obtained between April and June 2017 are included and divided by global regions. The map shows the number of case studies per region (number in brackets), their study type (top pie charts), scale of publication (middle pie charts) and group of ES assessed (bottom pie charts). Assessments at national or larger spatial scales are included in the map.

A higher number of studies was expected in the ORs, because of their closer legislative and administrative bonds with their respective EU Member States. However, this expected trend was not confirmed by the data. There were no clear differences between numbers of publications on ORs and OCTs or between northern or southern hemisphere. The numbers ranged from 4 publications in Guadeloupe to 18 on the Azores, which was the overall highest number on ES mapping and assessment-related studies in one of the regions considered in this review.

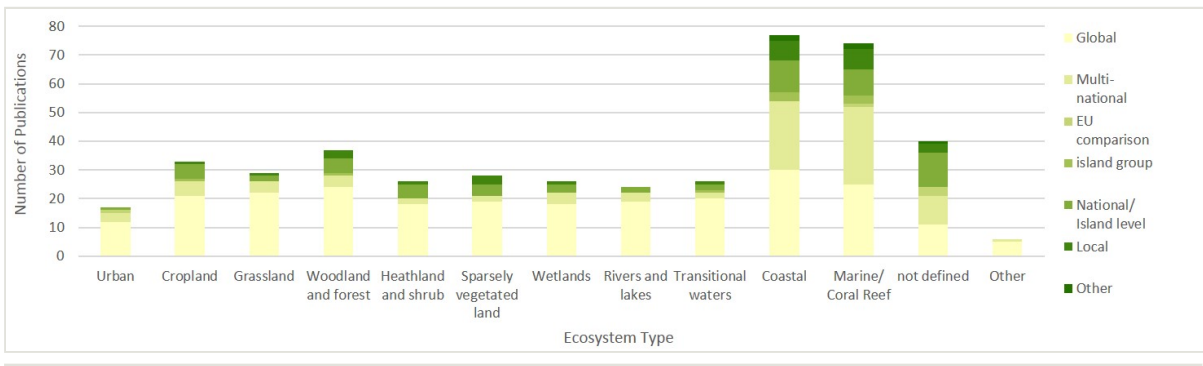

Figure 4.

Overview of ecosystem types described in the 161 ES mapping and assessment publications and the spatial extent at which they performed (global, multi-national, within the EU context, island group, island level or local). Publications that did not define any spatial scale of analysis were classified as 'undefined'. 
The majority of publications explicitly mentioned the ecosystem type in which the mapping activities took place (Fig. 4). Within the $161 \mathrm{ES}$ and benefit publications, an average of 2 ecosystems were mapped or assessed per publication. Most frequently, coastal and marine ecosystems were addressed $(77,74)$. Forty publications did not define the ecosystem type in which mapping and assessment took place. With 37 studies, woodlands and forests were the fourth most dominant land use types in the study regions, closely followed by cropland and agriculture (37). With only 17 publications, urban ecosystems received the least attention concerning mapping and assessment of ES. Habitat types such as deserts, tundra or ice and rock were included under type category "other", as in Kubiszewski et al. 2016.

\section{Short summary of the analysed studies}

After presenting the results of the systematic review of the mapping and assessment studies, a short overview of the information included in the publications is given. This overview elaborates the ES classification, spatial coverage as well as the enormous impacts of invasive species on ecosystems in ORs and OCTs. The 161 publications included 72 ES mapping studies, 85 ES assessment papers and 28 review papers (Fig. 5). Six papers proposed new ES indicators, for example for mapping of impacts of gold mining on soils (see, for example, Schimann et al. 2012) or indicators to classify marine habitats for mapping (e.g. Mumby and Harborne 1999) or for monitoring of Caribbean ecosystems (e.g. Verweij et al. 2015). Two publications were classified in more than one category as they combined indicator development with ES mapping or assessments (e.g.Chape 2006).

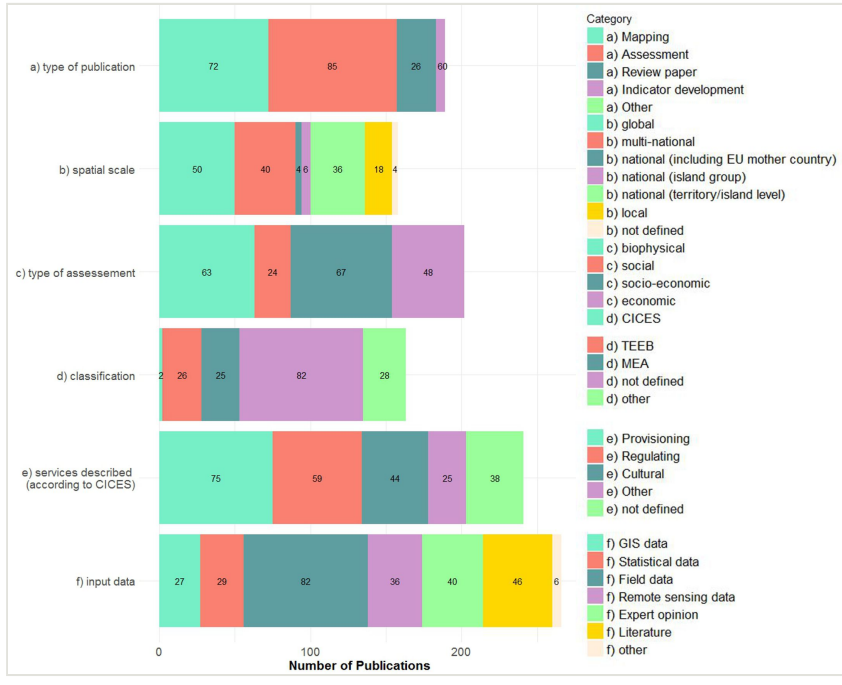

Figure 5.

Overview of the individual literature review data variables for Europes ORs and OCTs. Data variables include: (a) type of publication (192 counts); (b) spatial scale (161); (c) type of assessment (202); (d) ES Classifications used (168); (e) ES described in literature (233) and (f) input data used in publications (264). Multiple counts per study were possible. 
The ES classification applied in the study was left undefined in 82 publications (48\%). For the publications that defined the ES classification, authors mostly used the TEEB*9 (14\%) and the Millennium Ecosystem Assessment classification system (16\%). 17\% of all studies do not clearly define the classification of services described. Only $1 \%$ of all reviewed papers (i.e. 2 papers) applied the CICES classification (Picanço et al. 2017a, Pereira and Navarro 2015). Looking at the ES typology, we found that almost $30 \%$ of all reviewed papers mapped and/or assessed provisioning ES. 24\% referred to regulating ES and, independently of the classification system used to categorise the ES, $20 \%$ of all publications did not explicitly define any specific ES. These non-defined ES can partly be explained by the fact that monetary valuation of ecosystem types or aspects was often uncoupled from the individual ES provided in a specific ecosystem. With 17\%, cultural ES was the least covered ES category in ORs and OCTs (Fig. 5).

Spatial scales used to describe the individual ES in the publications were heterogeneous. 53 studies referred to global and multi-national scales. That means that more than half of all publications that describe ecosystems and their services used maps with comparably less detail and lower resolution. 12 publications mapped or valued ES for island groups and 40 publications referred to specific ORs and OCTs. Only 3 publications compared the ORs/OCTs and their respective EU Member States (e.g. Quintas-Soriano et al. 2016, Russi et al. 2016, Murillas-Maza et al. 2011). Notably, the majority of studies covers coastal and marine ecosystems mapped on global and international scale.

\section{Discussion}

The results show that the number of ES mapping and assessment publications in European OR and OCTs has been constantly increasing. In the following, we will discuss past and current ES mapping and assessment efforts, knowledge gaps and future research needs.

\section{Past and current ES mapping and assessment efforts}

In EU comparison, most ORs and OCTs still show slightly skewed publication numbers in a) geographical coverage and b) spatial scale.

a) In terms of geographical coverage, some regions have been mapped more than others. With 60 out of 161 publications, the Caribbean region is covered most extensively. However, as the Caribbean hosts 13 EU OCTs and ORs, this results in an average of 4.5 publications per region. In comparison, the Macaronesian region is only covered by 30 publications spread over 3 ORs, which results in a higher density of published studies with an average of 10 studies per OR. Furthermore, publications are not equally spread over the territories within each region. With a maximum of 18 mapping and assessment publications, this review found the Azores Archipelago leading in ES mapping and assessment efforts, a number that is average compared to continental Europe (Kopperoinen et al. 2016). On the contrary, some territories are not covered by any 
mapping or assessment study, such as Saint-Pierre and Miquelon, the British Antarctic Territories, Scattered Islands, Madeira, Tristan da Cunha, Ascension Island, Anguilla, Saint Martin or Aruba.

There are several explanations for the overall low number of publications mapping EU overseas. Firstly, the legal complexity of EU law in ORs and OCTs obscures the necessity to implement the EU Biodiversity Strategy overseas. Whereas ORs are obliged to implement all EU laws and legislation, the legal status of the OCTs can differ for each territory (Kochenov 2013). Though most EU Member States with bonds to ORs and OCTs explicitly mention ES in their overseas territories nature conservation plans (Ministerie van Economische Zaken 2013, UK Government 2014), the number of peer-reviewed publications is astonishingly low. This can be explained by the fact that none of the policy plans refers to the EU Biodiversity Strategy or define assessment targets or MAES strategies within their policies. In addition, the voluntary schemes fostering MAES in overseas have not yet focused on ES specifically. Their latest output, regional ecosystem profiles 4 , have been focused on biodiversity, listing species, defining Key Biodiversity Areas (KBA) and exploring Marine Protected Areas (MPA), listing existing projects and their assessment efforts. ES maps, however, are generally lacking.

The lack of ES maps can be explained by three factors. Firstly by the fact that such efforts usually take place on local scales and refer more to policy than to scientific levels. Therefore, peer-reviewed publications are often lacking for ORs and OCTs. Even though this review considered grey literature, existing efforts that are of internal nature and not publicly available could not be included in this review. Secondly, the remoteness and relatively small size of most regions encroach upon the importance of ORs and OCTs, because their contribution to EU Member States is often small in terms of economic impact or benefits (ten Brink et al. 2017). Therefore, coordinated MAES efforts are still rare, with no coherent databases in which ES mapping or assessment studies have been published. Thirdly, data availability and research efforts are still scarce in ORs and OCTs. Whereas continental Europe provides detailed ecosystem maps and land use and land cover data, the EU overseas areas are still much less explored and data collection on an island scale is expensive. Our results show that only where universities have become involved in ES mapping, assessment, data collection and ground truthing, good efforts can be seen, such as on the Azores or Bonaire and Sint Eustatius in the Dutch Caribbean.

b) In terms of spatial scale, the review showed that mapping and assessment of ecosystems and their services takes place on multiple scales, including local (e.g. provisioning ES of fishing capacity and effort (Thiault et al. 2017)), regional (e.g. cultural ES of experiencing marine wildlife (Roberts et al. 2017)) to global (e.g. regulating ES of hazard risk reduction provided by coral reefs (Ferrario et al. 2014)). In contradiction to the findings of Malinga et al. 2015, who found that almost all their reviewed ES mapping studies referred to municipal, regional and national levels, this review found 97 publications $(60 \%)$ on MAES in ORs and OCTs on a global or multi-national scale. Furthermore, these 97 studies covered approximately $70 \%$ of all ecosystem types and their services described in all 161 publications in this review. Such global and multinational studies represented the only sources of information on ES mapping and assessment for territories such as Saint 
Helena, the Sandwich Islands or the Kerguelen Islands. Nonetheless, in most of these global and multinational publications, the smaller ORs and OCTs are invisible on the maps, such as by Ghermandi and Nunes 2013 study on coastal recreation values, by Li and Fang 2014 on global ES values and their relation to GDP or Sutton et al. 2012 on the human ecological footprint.

We need to acknowledge that such global and multinational publications are important to provide a good overview and raise awareness on biodiversity and ES globally and multinationally. However, at policy level, it is important to understand where and what services are provided by an ecosystem, island, region or globally in order to monitor the achievement of policy goals (Crossman et al. 2013), such as the EU Biodiversity Strategy's target 2 . This review found only 64 publications (40\%) that describe ecosystems and their services on national or local level (46; 18 publications, respectively). However, maps on small to intermediate spatial scales are needed if data should feed into land use or land management plans for the 34 overseas regions. Hence, such global or multinational studies have limited value for the individual EU territories in communicating data and information locally, as their resolution is too coarse. Therefore, such studies would be illsuited to feed into local land use planning and decision-making concerning natural resources management.

Hence, both geographical and spatial coverage show fragmented ES mapping and assessment efforts in EU ORs and OCTs. Based on this fact and the general outcomes of the review, the following knowledge gaps were identifietd.

\section{Knowledge gaps}

Several knowledge gaps related to dealing with diverging conceptual frameworks, lacking knowledge on mapping and assessing island ES, the role of key biodiversity areas and marine protected areas, applied methods as well as information sharing, were identified for the ORs and OCTs:

a) The lack of common conceptual frameworks to analyse ES seems to be obvious in ORs and OCTs. Rather, a broad variety of concepts was found within the publications. The European Commission has set up a common conceptual ES framework within the EU Biodiversity Strategy (Maes et al. 2016, Maes et al. 2013). This framework builds upon the Common International Classification of Ecosystem Services (CICES*3) and tries to ensure consistent approaches (Maes et al. 2016). EU wide, CICES is applied broadly. However, in the ORs and OCTs, only two studies using CICES were found (in the Azores; Cerqueira et al. 2015, Picanço et al. 2017a). This low application rate of CICES was surprising and, considering the efforts to implement MAES in ORs and OCTs, it gives rise to the following questions: Is CICES sufficiently known outside of mainland Europe? Is it too complex or too new to be applied? Or does it just not fit the ORs and OCTs, be it due to the geographic characteristics (e.g. specific land use types and related ES; small area effects), the remoteness of the territories or their special situation, leading to a shift in focus out of EU efforts? Although the MEA classification has found much more application in ES mapping and assessment 
publications, still different conceptual frameworks have been applied. Hardly any mapping publication in this review used the same methodologies or used the same indicators to map ES. Only amongst the economic assessment publications, congruencies in methodologies was found. An example of consistent ES valuation throughout a whole region is shown by the extensive works assessing the economic value of ES in the Dutch Caribbean (Slootweg and Van Beukering 2008, Schep et al. 2012, van der Lely et al. 2013, van Zanten et al. 2014, Tieskens et al. 2014). These studies mainly applied the TEEB classification and used economic valuation methods such as Contingent Valuation, Willingness to Pay or Total Economic Value.

b) This literature review showed a general lack of knowledge on mapping island ecosystems and the services they provide. As the current MAES efforts mainly focus on specific ecosystems, adjusted for continental Europe, comprehensive island ES maps are lacking. This review shows that trends observed in ES research in ORs and OCTs differ from European MAES efforts. Most comparable (global) literature reviews have found a strong focus on regulating ES (e.g. Malinga et al. 2015, Egoh et al. 2012, Martínez-Harms and Balvanera 2012). Our review, looking solely at ORs and OCTs, however, highlights that, in most studies, provisioning ES were mapped or assessed (74), followed by regulating ES (58). Cultural ES were mapped the least, with only 42 publications. This can probably be explained through the strong reliance of ORs and OCTs on marine and coastal ES related to tourism or fisheries. The diverging conceptual frameworks adopted in the reviewed publications suggest a need to adapt international ES classification systems to regional and local (island) needs.

c) Mapping in ORs and OCTs has often been reduced to key biodiversity areas (KBA) or marine protected areas (MPA) (Knowles et al. 2015, Fonseca et al. 2014). However, the relationship between protected areas and the enhanced provision of ES is highly debated (Boersma and Parrish 1999, Halpern et al. 2010), arguing that the establishment of MPAs is not necessarily leading to increased ES supply. Their efficacy on

local scale is acknowledged, however, the flexible nature of resources (fish stock, larvae), the pressure of invasive species and chemical and biological pollutants affecting protected coastal ecosystems and the often inadequate size of the parks are amongst the main criticisms (Boersma and Parrish 1999). Other scholars argue that, if managed properly, MPAs strongly contribute to species diversity, ecosystem health and tourism (Leenhardt et al. 2015). Even though the number of MPAs is still growing exponentially since the last decade* 10 , this review found few comprehensive examples from practice, proving such a positive relation in EU ORs and OCTs. Few publications in the Caribbean and the Azores link MPAs with ES (Leenhardt et al. 2015, Waite et al. 2015, Beaumont et al. 2007), focussing on cultural ES (key species, recreational activities in MPAs (e.g. Green and Donnelly 2003, Roberts et al. 2017). Only one study investigated the complex interplay of multiple ES (Leenhardt et al. 2015) but ES supply dynamics related to MPA installations remain unstudied. Not surprisingly, there are few maps of ES provided by OR- or OCT-related MPAs (Green 
and Donnelly 2003). Exploring this link will be key in optimising effective management of European MPAs to safeguard the provision of multiple ES simultaneously.

d) Most of the reviewed studies were applying economic and biophysical/ecological mapping and assessment methods. ES supply and demand are, however, embedded in the complex human-environmental system, requiring transdisciplinary research approaches that integrate methods and value domains from ecological, economic and social sciences. Our review found that researchers often apply methods that they are familiar with. Moreover, data sets used for research might contain gaps. As already described by Eppink et al. 2012, data sets used for ES mapping and assessment might have been collected using inconsistent methods, indicators or leaving out processes crucial for the understanding of ES supply (Eppink et al. 2012). Therefore, there is a need to apply and interlink methods from different scientific disciplines and to communicate the reliability and uncertainties of resulting ES maps.

e) In addition, ways to store information on ES such as related data, metadata, maps and the like differ. Existing EU platforms to share case studies and publications are largely unused for ORs and OCTs, as the screening of databases like BISE*6, ESP Visualization $\mathrm{Tool}^{\star} 7$ or OPPLA${ }^{\star} 8$ showed. Here, there is great potential for knowledge, data and information exchange for the future and in support of MAES implementation in EU ORs and OCTs.

\section{The role of invasive species in ORs and OCTs}

Biological invasions are a shared problem in all regions - about $25 \%$ of all reviewed studies mentioned invasive species and ecosystem disservices linked to alien flora and fauna. With typically limited biodiversity on islands, invasive species can alter ecosystem structures and processes and hence impact the provision of ES (e.g. Vila and Hulme 2017), often with yet unknown consequences. Invasive species such as termites have been mapped or assessed for the Caribbean region (Evans et al. 2013) and the West Indian Drywood Termite in the Azores (Borges et al. 2014, Guerreiro et al. 2014). Such invasive species flourish as trade and tourism increase and remoteness is no longer a geographical barrier (Vila and Hulme 2017). These changes in ecosystems and their services can also be observed in the marine realm, where invasive species are not restricted by any borders and have spread over all oceans, as shown in publications on mapping salmonids in the French Antarctic Territories, amphipods or lionfish in the Caribbean (Lecomte et al. 2013, RoganFinnemore 2008; van Beukering et al. 2014). Other examples can be found by the Government of the Falkland Islands, one of the few OCTs that systematically analysed threats and opportunities linked to invasive species (Upson et al. 2016). In Macaronesian islands, an exhaustive systematic study was performed to list the TOP100 most invasive species (Silva et al. 2008).

Whereas non-native invasive species have long been recognised as the largest cause of species loss in island ecosystems, the link between alien species and ecosystem (dis)services has just recently been established (Yam et al. 2015, Vila and Hulme 2017) and will need to be addressed urgently across EU overseas territories in the near future. 
However, exotic and/or invasive species may also provide ES (e.g. alien plants can increase microbial activity) and introduced natural enemies can control pests (Vilà et al. 2011). Also relevant was the result obtained by Rigal et al. 2018 on the impact of land-use changes on the functional role of exotic and native arthropods in the Azores. The main finding was that there is a potential functional complementarity between indigenous and exotic species, which means that, in agricultural landscapes, exotic species might provide and maintain key ecosystem functions (Rigal et al. 2018). However, pollinator native species may also contribute to pollination services in human-made habitats and may promote the spread of invasive plants, as seen in the Azores (Picanço et al. 2017b). Therefore, the link between invasive species and ES or disservices needs further exploration.

\section{Future research needs for MAES implementation in ORs and OCTs}

The high number of publications on biodiversity and ecosystem conditions in ORs and OCTs clearly indicates the importance of flora, fauna and habitats of the ORs and OCTs. As the numbers of publications on invasive species showed, there is an urgent need for nature conservation action. Moreover, there is the need to understand the role of exotic and invasive species on both ES and disservices in island native and human-made habitats. It is also important to identify the role of native insect pollinators or native birds as promoters of disservices, namely on helping plant invasions through, for instance, seed dispersal.

This review has found no studies that were officially carried out under the umbrella of MAES. Only a few studies have effectively identified or defined the goods and services derived from ecosystems and only a fraction of these publications mapped or assessed the respective ES. Past and current efforts are still skewed in terms of geographical and spatial coverage and conceptual frameworks diverge. In addition, data and the process of translating biodiversity and environmental studies into ES maps have still not clearly been communicated. Combined, these three areas of concern lead to limited comparability of studies across the EU, the overseas regions, landscapes and amongst ES maps. Experts criticise that such a broad variability, in technical and contextual aspects, would make it difficult to assess the individual and political value of such studies (Eppink et al. 2012). Such comparability, however, is needed - at least to some extent - to include the ORs and OCTs in MAES comparisons, within their related EU Member States as well as EU wide.

To enhance comparability between ES mapping and assessment studies, developing a standardised approach or one-size-fits-all solution would be unfavourable for the ORs and OCTs. Due to their immense diversity and special needs, such standardised approaches or lessons learned from continental EU might fail to obtain the data on ES mapping and assessment needed to enhance local decision-making and natural resources management. Rather, a flexible, guidance-based approach based on the vast knowledge on ES mapping and assessment from around the world needs to be developed, taking into consideration the individual ORs' or OCTs' needs. We strongly believe that developing such a flexible guidance for mapping and assessing ES that focuses on smaller spatial scales and finer resolutions can enhance local resources management for multiple, interacting ES 
bundles and a sustainable land management and biodiversity conservation in ORs and OCTs.

To achieve the targets of the EU Biodiversity Strategy 2020, a stronger emphasis on ES in the governance of ORs' and OCTs' natural resources and policy is needed. The MAES initiative needs much more exposure outside of continental Europe. Rather than solely placing the ES concept in the overseas policy plans of related EU Member States, the ES concept needs anchoring in national nature conservation and decision-making efforts as well as in local societies and cultures of the overseas regions, countries and territories. Voluntary programmes, such as the BEST initiative, are a step in the right direction. Capacity building amongst relevant stakeholders is required to transfer the ES concept from science into practice.

\section{Concluding remarks: moving forward}

Our review shows that current efforts from within the regions as well as from the European Commission to strengthen MAES in ORs and OCTs are still scarce. Nonetheless, general scientific literature on ES mapping and assessment is growing. The NetBiome and EUBEST projects mark a good beginning with their regional reports of ecosystem profiles and overviews of existing initiatives to protect ES and biodiversity for each region. However, even though there is much information on biodiversity and ecosystems for the seven global regions, a transparent translation into ES maps and assessments still needs to be done. Integrated, standardised ES assessments are often missing and mapping studies often entail scale-mismatches, conducted on global or multi-national scale. Hence, ES mapping and assessment still contribute little to policy and decision-making related to natural resources and conservation management on local or regional scales.

This literature review shows that efforts are still needed for most ORs and OCTs to meet the aims of Action 5 of Target 2 of the EU Biodiversity Strategy 2020. Therefore, we call for the development of a more flexible, guidance-based approach for ES mapping and assessment of EU overseas, including researchers from multiple disciplines and sectors to provide a comprehensive overview of the current status of biodiversity, ecosystems and the services they provide. This requires strong emphasis on MAES from the ORs and OCTs, their related EU Member States as well as from the European Commission. The ESMERALDA project has developed the scientific and methodological background (e.g. Burkhard and Maes 2017) and started MAES-related knowledge exchange with the ORs and OCTs. The recent call from the EC for projects on "Mapping and Assessing the state of Ecosystems and their Services in the Outermost Regions and Overseas Countries and Territories: establishing links and pooling resources" (Ref.: ENV/2017/CFP/MAES-OROCT) and the launch of the MOVE (Facilitating MAES to support regional policy in OVerseas Europe: mobilising stakeholders and pooling resources) project support our findings and have the potential to kick-start research on mapping and assessment of ES in Europe's Overseas. 
To reach the EU Biodiversity Strategy's target of EU wide, comprehensive maps of ecosystems and their services and the integration of such ES values into national accounting systems by 2020, urgent actions are needed in ORs and OCTs, as overexploitation of natural resources and degradation of habitats through invasive species proceed unaltered. With proceeding climatic change, ES are a suitable tool to promote the protection of coastal habitats and natural protection structures. ES maps can raise awareness, reveal ES supply-demand mismatches and thereby reduce vulnerability of EU overseas areas.

\section{Acknowledgements}

This study was funded by the Coordination and Support Action ESMERALDA. This project receives funding from the European Union's Horizon 2020 research and innovation programme under grant agreement No 642007.

\section{Author contributions}

IMS and BB conceived the study. IMS and BB designed the sampling strategy. The literature review was performed by IMS. IMS created the maps and wrote main parts of the paper, with input from all authors. IMS, BB and PAVB contributed to readjustments on previous drafts.

\section{References}

- $\quad$ Bastian O, Haase D, Grunewald K (2012) Ecosystem properties, potentials and services - The EPPS conceptual framework and an urban application example. Ecological Indicators 21: 7-16. https://doi.org/10.1016/j.ecolind.2011.03.014

- Beaumont NJ, Austen MC, Atkins JP, Burdon D, Degraer S, Dentinho TP, Derous S, Holm P, Horton T, lerland Ev, Marboe AH, Starkey DJ, Townsend M, Zarzycki T (2007) Identification, definition and quantification of goods and services provided by marine biodiversity: Implications for the ecosystem approach. Marine Pollution Bulletin 54 (3): 253-265. https://doi.org/10.1016/j.marpolbul.2006.12.003

- Boersma PD, Parrish JK (1999) Limiting abuse: marine protected areas, a limited solution. Ecological Economics 31 (2): 287-304. https://doi.org/10.1016/s0921-8009 (99)00085-3

- $\quad$ Borges PA, Azevedo EB, Borba A, Dinis FO, Gabriel R, Silva E (2009) Ilhas Oceânicas. In: Pereira HM, Domingos T, Vicente L, Proença V (Eds) Ecossistemas e bem-estar humano em Portugal: Avaliação para Portugal do Millennium Ecosystem Assessment. Escolar Editora, Lisboa, 463-510 pp. [In Portuguese]. URL: http://

hdl.handle.net/10400.3/2011

- $\quad$ Borges PA, Guerreiro O, Ferreira MT, Borges A, Ferreira F, Bicudo N, Nunes L, Marcos RS, Arroz AM, Scheffrahn RH, Myles TG (2014) Cryptotermes brevis(Isoptera: Kalotermitidae) in the Azores: Lessons After $2 \mathrm{yr}$ of Monitoring in the Archipelago. Journal of Insect Science 14 (1): 172. https://doi.org/10.1093/isesa/ieu034 
- $\quad$ Bouwma I, Schleyer C, Primmer E, Winkler KJ, Berry P, Young J, Carmen E, Špulerová J, Bezák P, Preda E, Vadineanu A (2018) Adoption of the ecosystem services concept in EU policies. Ecosystem Services 29: 213-222. https://doi.org/10.1016/ j.ecoser.2017.02.014

- Brown C, Potschin M, Haines-Young R, Burns A, Arnell A (2018) ESMERALDA Integrated Ecosystem Assessment. One Ecosystem 3: e25482. URL: https:// doi.org/10.3897/oneeco.3.e25482

- $\quad$ Burkhard B, Kroll F, Nedkov S, Müller F (2012) Mapping ecosystem service supply, demand and budgets. Ecological Indicators 21: 17-29. https://doi.org/10.1016/ j.ecolind.2011.06.019

- $\quad$ Burkhard B, Maes J (Eds) (2017) Mapping Ecosystem Services. Pensoft [ISBN 9789546428295]

- $\quad$ Cerqueira Y, Navarro LM, Maes J, Marta-Pedroso C, Pradinho Honrado J, Pereira H (2015) Ecosystem Services. The Opportunities of Rewilding in Europe. In: Pereira H, Navarro L (Eds) Rewilding European Landscapes. Springer International Publishing, 223 pp. [ISBN 978-3-319-12039-3].

- $\quad$ Chape $S$ (Ed.) (2006) Review of environmental issues in the pacific region and the role of the pacific regional environment programme. Workshop and symposium on Collaboration for sustainable development of the Pacific Islands: Towards effective elearning systems on environment. Okinawa, Japan.

- $\quad$ Crossman N, Burkhard B, Nedkov S (2012) Quantifying and mapping ecosystem services. International Journal of Biodiversity Science, Ecosystem Services \& Management 8: 1-4. https://doi.org/10.1080/21513732.2012.695229

- $\quad$ Crossman N, Burkhard B, Nedkov S, Willemen L, Petz K, Palomo I, Drakou E, MartínLopez B, McPhearson T, Boyanova K, Alkemade R, Egoh B, Dunbar M, Maes J (2013) A blueprint for mapping and modelling ecosystem services. Ecosystem Services 4:

4-14. https://doi.org/10.1016/j.ecoser.2013.02.001

- De Knegt B (2014) Graadmeter Diensten van Natuur; Vraag, aanbod, gebruik en trend van goederenen diensten uit ecosystemen in Nederland. Wettelijke Onderzoekstaken Natuur \& Milieu,; Alterra-Wageningen. WOt-technicalreport, 13. Alterra, Wageningen, $227 \mathrm{pp}$.

- Douine M, Mosnier E, Hingrat QL, Charpentier C, Corlin F, Hureau L, Adenis A, Lazrek Y, Niemetsky F, Aucouturier A, Demar M, Musset L, Nacher M (2017) Illegal gold miners in French Guiana: a neglected population with poor health. BMC Public Health 18 (1): 23. https://doi.org/10.1186/s12889-017-4557-4

- Drakou EG, Crossman ND, Willemen L, Burkhard B, Palomo I, Maes J, Peedell S (2015) A visualization and data-sharing tool for ecosystem service maps: Lessons learnt, challenges and the way forward. Ecosystem Services 13: 134-140. https:// doi.org/10.1016/i.ecoser.2014.12.002

- $\quad$ Egoh B, Drakou E, Dunbar M, Maes J, Willemen L (2012) Indicators for mapping ecosystem services: a review. JRC Scientific and Policy Reports, Luxembourg: Publications Office of the European Union, 113 pp. [ISBN 978-92-79-25821-3] https:// doi.org/10.2788/41823

- $\quad$ Eppink F, Werntze A, Mäs S, Popp A, Seppelt R (2012) Land Management and Ecosystem Services How Collaborative Research Programmes Can Support Better Policies. GAIA - Ecological Perspectives for Science and Society 21 (1): 55-63. https:// doi.org/10.14512/gaia.21.1.14 
- $\quad$ EU (2016) Consolidated version of the Treaty on the Functioning of the European Union. In: Official. Journal of the European Union C 202 (1): 195.

- European Commission (2008) Message from Reunion Island. The European Union and its OverseasEntities: Strategies to counter Climate Change and Biodiversity Loss, Reunion Island, 07.-11.06.2008. European Commission, 20 pp.

- European Commission (2011) Our life insurance, our natural capital: an EU biodiversity strategy to 2020. Communication from the Commission to the European Parliament, the Council, the Economic and Social Committee and the Committee of Regions, Brussels, Belgium, $17 \mathrm{pp}$.

- $\quad$ Evans T, Forschler B, Grace JK (2013) Biology of Invasive Termites: A Worldwide Review. Annual Review of Entomology 58 (1): 455-474. https://doi.org/10.1146/annurevento-120811-153554

- $\quad$ Ferrario F, Beck M, Storlazzi C, Micheli F, Shepard C, Airoldi L (2014) The effectiveness of coral reefs for coastal hazard risk reduction and adaptation. Nature Communications 5 https://doi.org/10.1038/ncomms4794

- Fonseca C, da Silva CP, Calado H, Moniz F, Bragagnolo C, Gil A, Phillips M, Pereira M, Moreira M (2014) Coastal and marine protected areas as key elements for tourism in small islands. Journal of Coastal Research 70: 461-466. https://doi.org/10.2112/ si70-078.1

- $\quad$ Ghermandi A, Nunes PL (2013) A global map of coastal recreation values: Results from a spatially explicit meta-analysis. Ecological Economics 86: 1-15. https:// doi.org/10.1016/j.ecolecon.2012.11.006

- $\quad$ Green E, Donnelly R (2003) Recreational Scuba Diving In Caribbean Marine Protected Areas: Do The Users Pay? AMBIO: A Journal of the Human Environment 32 (2): 140. https://doi.org/10.1639/0044-7447(2003)032[0140:rsdicm]2.0.co;2

- $\quad$ Guerreiro O, Cardoso P, Ferreira JM, Ferreira MT, Borges PA (2014) Potential Distribution and Cost Estimation of the Damage Caused by Cryptotermes brevis (Isoptera: Kalotermitidae) in the Azores. Journal of Economic Entomology 107 (4): 1554-1562. https://doi.org/10.1603/ec13501

- Haines-Young R, Potschin M (2010) The links between biodiversity, ecosystem services and human well-being. Ecosystem Ecology. https://doi.org/10.1017/

cbo9780511750458.007

- Halpern BS, Lester SE, McLeod KL (2010) Placing marine protected areas onto the ecosystem-based management seascape. Proceedings of the National Academy of Sciences 107 (43): 18312-18317. https://doi.org/10.1073/pnas.0908503107

- Heron S, Maynard J, Hooidonk Rv, Eakin CM (2016) Warming Trends and Bleaching Stress of the World's Coral Reefs 1985-2012. Scientific Reports 6 (1): . https:// doi.org/10.1038/srep38402

- Hutchings J (2000) Collapse and recovery of marine fishes. Nature 406 (6798): 882-885. https://doi.org/10.1038/35022565

- IUCN (2014) Message from Guadeloupe. https://www.iucn.org/sites/dev/files/import/ downloads/message from guadeloupe en 2 .pdf. Accessed on: 2018-2-10.

- Knowles J, Doyle E, Schill S, Roth L, Milam A, Raber G (2015) Establishing a marine conservation baseline for the insular Caribbean. Marine Policy 60: 84-97. https:// doi.org/10.1016/j.marpol.2015.05.005

- Kochenov D (2013) The Application of EU Law in the EU's Overseas Regions, Countries, and Territories After the Entry into Force of The Treaty of Lisbon. 
International Law Review 20 (3): 269-743. URL: https://digitalcommons.law.msu.edu/ilr/ vol20/iss3/1

- $\quad$ Kopperoinen L, Maes J, Streberová E, Pártl A, Pitkänen K, Virag-Prokai R (2016)

Ecosystem service mapping and assessment gaps in EU member states and recommendations to overcome them. Deliverable 2.2., EU Horizon 2020 ESMERALDA Project, Grant agreement No. 642007. 41 pp.

- Kubiszewski I, Anderson S, Costanza R, Sutton P (2016) The Future of Ecosystem Services in Asia and the Pacific. Asia \& the Pacific Policy Studies 3 (3): 389-404. https:// doi.org/10.1002/app5.147

- $\quad$ Lecomte F, Beall E, Chat J, Davaine P, Gaudin P (2013) The complete history of salmonid introductions in the Kerguelen Islands, Southern Ocean. Polar Biology 36 (4): 457-475. https://doi.org/10.1007/s00300-012-1281-5

- Leenhardt P, Low N, Pascal N, Micheli F, Claudet J (2015) The Role of Marine Protected Areas in Providing Ecosystem Services. Aquatic Functional Biodiversity. https:// doi.org/10.1016/b978-0-12-417015-5.00009-8

- $\quad$ Li G, Fang C (2014) Global mapping and estimation of ecosystem services values and gross domestic product: A spatially explicit integration of national 'green GDP' accounting. Ecological Indicators 46: 293-314. https://doi.org/10.1016/ j.ecolind.2014.05.020

- $\quad$ Liquete C, Piroddi C, Drakou E, Gurney L, Katsanevakis S, Charef A, Egoh B (2013) Current Status and Future Prospects for the Assessment of Marine and Coastal Ecosystem Services: A Systematic Review. PLoS ONE 8 (7): e67737. https:// doi.org/10.1371/journal.pone.0067737

- Maes J, Teller A, Erhard M, Liquete C, Braat L, Berry P, Egoh BN, Puydarrieux P, Fiorina C, Santos-Martín F, al e (2013) Mapping and Assessment of Ecosystems and their Services - An analytical framework for ecosystem assessments under Action 5 of the EU Biodiversity Strategy to 2020. Discussion paper. Publications Office of the European Union [ISBN 978-92-79-29369-6] https://doi.org/10.2779/12398

- Maes J, Liquete C, Teller A, Erhard M, Paracchini ML, Barredo J, Grizzetti B, Cardoso A, Somma F, Petersen J, Meiner A, Gelabert ER, Zal N, Kristensen P, Bastrup-Birk A, Biala K, Piroddi C, Egoh B, Degeorges P, Fiorina C, Santos-Martín F, Naruševičius V, Verboven J, Pereira H, Bengtsson J, Gocheva K, Marta-Pedroso C, Snäll T, Estreguil C, San-Miguel-Ayanz J, Pérez-Soba M, Grêt-Regamey A, Lillebø A, Malak DA, Condé S, Moen J, Czúcz B, Drakou E, Zulian G, Lavalle C (2016) An indicator framework for assessing ecosystem services in support of the EU Biodiversity Strategy to 2020. Ecosystem Services 17: 14-23. https://doi.org/10.1016/j.ecoser.2015.10.023

- Malinga R, Gordon L, Jewitt G, Lindborg R (2015) Mapping ecosystem services across scales and continents - A review. Ecosystem Services 13: 57-63. https:// doi.org/10.1016/i.ecoser.2015.01.006

- Martínez-Harms MJ, Balvanera P (2012) Methods for mapping ecosystem service supply: a review. International Journal of Biodiversity Science, Ecosystem Services \& Management 8: 17-25. https://doi.org/10.1080/21513732.2012.663792

- Millennium Ecosystem Assessment (2005) Ecosystems and Human Well-Being: Current State and Trends. Millennium Ecosystem Assessment, 948 pp. [ISBN 9781559632270]

- Ministère de l'Environnement, de l'Énergie, et de la Mer (2015) Cadre conceptuel et glossaire. L'Évaluation Française des Écosystèmes et des Services Écosystémiques (EFESE). [MEDDE]. 
- Ministerie van Economische Zaken (2013) Nature Policy Plan - The Caribbean Netherlands 2013-2017. Ministerie van Economische Zaken, Directie Natuur en Biodiversiteit, 54 pp. URL: https://www.government.nl/documents/ publications/2014/02/03/nature-policy-plan-the-caribbean-netherlands

- Moher D (2009) Preferred Reporting Items for Systematic Reviews and Meta-Analyses: The PRISMA Statement. Annals of Internal Medicine 151 (4): 264. https:// doi.org/10.7326/0003-4819-151-4-200908180-00135

- Mumby P, Harborne A (1999) Development of a systematic classification scheme of marine habitats to facilitate regional management and mapping of Caribbean coral reefs. Biological Conservation 88 (2): 155-163. https://doi.org/10.1016/s0006-3207 (98)00108-6

- $\quad$ Murillas-Maza A, Virto J, Gallastegui MC, González P, Fernández-Macho J (2011) The value of open ocean ecosystems: A case study for the Spanish exclusive economic zone. Natural Resources Forum 35 (2): 122-133. https://doi.org/10.1111/

j.1477-8947.2011.01383.x

- $\quad$ Nunes PA, Ghermandi A, Onofri L (2014) Guidance manual on valuation and accounting of ecosystem services for small island developing states. UNEP, EcosystemServices Economics Unit, Division of Environmental Policy Implementation, 128 pp. [ISBN 978-92-807-3407-2].

- $\quad$ Pereira H, Navarro L (2015) Rewilding European Landscapes. Springer International Publishing, Cham.

- $\quad$ Pereira HM, Domingos T, Vicente L (Eds) (2009) Portugal Millennium Ecosystem Assessment: State of the Assessment Report. Centro de Biologia Ambiental, Faculdade de Ciências da Universidade de Lisboa. URL: http://ecossistemas.org

- $\quad$ Petit J, Prudent G (2008) Climate Change and Biodiversity in the European Union Overseas Entities. IUCN, Gland, Switzerland and Brussels, Belgium., 192 pp.

- $\quad$ Picanço A, Gil A, Rigal F, Borges PV (2017a) Pollination services mapping and economic valuation from insect communities: a case study in the Azores (Terceira Island). Nature Conservation 18: 1-25. https://doi.org/10.3897/ natureconservation.18.11523

- $\quad$ Picanço A, Rigal F, Matthews T, Cardoso P, Borges PV (2017b) Impact of land-use change on flower-visiting insect communities on an oceanic island. Insect Conservation and Diversity 10 (3): 211-223. https://doi.org/10.1111/icad.12216

- Quintas-Soriano C, Martín-López B, Santos-Martín F, Loureiro M, Montes C, Benayas J, García-Llorente M (2016) Ecosystem services values in Spain: A meta-analysis.

Environmental Science \& Policy 55: 186-195. https://doi.org/10.1016/ j.envsci.2015.10.001

- $\quad$ Rigal F, Cardoso P, Lobo J, Triantis K, Whittaker R, Amorim I, Borges PV (2018) Functional traits of indigenous and exotic ground-dwelling arthropods show contrasting responses to land-use change in an oceanic island, Terceira, Azores. Diversity and Distributions 24 (1): 36-47. https://doi.org/10.1111/ddi.12655

- Roberts M, Hanley N, Cresswell W (2017) User fees across ecosystem boundaries: Are SCUBA divers willing to pay for terrestrial biodiversity conservation? Journal of Environmental Management 200: 53-59. https://doi.org/10.1016/j.jenvman.2017.05.070

- Rodrigues JG, Conides A, Rodriguez SR, Raicevich S, Pita P, Kleisner K, Pita C, Lopes P, Roldán VA, Ramos S, Klaoudatos D, Outeiro L, Armstrong C, Teneva L, Stefanski S, Böhnke-Henrichs A, Kruse M, Lillebø A, Bennett E, Belgrano A, Murillas A, Pinto IS, 
Burkhard B, Villasante S (2017) Marine and Coastal Cultural Ecosystem Services: knowledge gaps and research priorities. One Ecosystem 2: e12290. https:// doi.org/10.3897/oneeco.2.e12290

- Rogan-Finnemore M (2008) Non-native species in the Antarctic. Proceedings. Christchurch, N.Z: Gateway Antarctica, Centre for Antarctic Studies and Research, University of Canterbury (Gateway Antarctica special publication series, no. 0801). Research, University of Canterbury (Gateway

- Russi D, Pantzar ;, Kettunen M, Gitti G, Mutafoglu K, Kotulak M, ten Brink P (2016) Socio-Economic Benefits of the EU Marine Protected Areas. Report prepared by the Institute for European Environmental Policy (IEEP) for DG Environment, $96 \mathrm{pp}$.

- Santos-Martín F, García-Llorente M, Quintas-Soriano C, Zorrillas-Miras P, Martín-Lopez B, Loureiro M (2016) Spanish National Ecosystem Assessment: Socio-economic valuation of ecosystem services in Spain. Synthesis of key findings. Biodiversity Foundation of the Spanish Ministry of Agriculture, Food and Environment., Madrid, Spain, 68 pp. [ISBN 978-84-608-8776-8]

- $\quad$ Schep S, Johnson A, Beukering P, Esther Wolfs (2012) The fishery value of coral reefs in Bonaire. IVM Institute for Enironmental Studies. The Netherlands

- Schimann H, Petit-Jean C, Guitet S, Reis T, Domenach AM, Roggy J (2012) Microbial bioindicators of soil functioning after disturbance: The case of gold mining in tropical rainforests of French Guiana. Ecological Indicators 20: 34-41. https://doi.org/10.1016/ j.ecolind.2012.01.021

- $\quad$ Schröter M, Albert C, Marques A, Tobon W, Lavorel S, Maes J, Brown C, Klotz S, Bonn A (2016) National Ecosystem Assessments in Europe: A Review. BioScience 66 (10): 813-828. https://doi.org/10.1093/biosci/biw101

- $\quad$ Silva L, Land EO, Rodríguez Luengo JL (2008) Invasive terrestrial flora \& fauna of Macaronesia. TOP 100 in Azores, Madeira and Canaries. ARENA, Ponta Delgada. URL: https://repositorio.uac.pt/handle/10400.3/1978 [ISBN 978-989-95910-1-1]

- $\quad$ Slootweg R, Van Beukering PJH (2008) Valuation of ecosystem services and strategic environmental assessment-Lessons from influential cases. In: Slootweg R,, Rajvanshi A,, Mathur VB, Kolhoff A (Eds) Biodiversity in environmental assessment: enhancing ecosystem services for human well-being. Cambridge University Press.

- Sutton P, Anderson S, Tuttle B, Morse L (2012) The real wealth of nations: Mapping and monetizing the human ecological footprint. Ecological Indicators 16: 11-22. https:// doi.org/10.1016/i.ecolind.2011.03.008

- $\quad$ Syrbe R, Schorcht M, Grunewald K, Meinel G (2017) Indicators for a nationwide monitoring of ecosystem services in Germany exemplified by the mitigation of soil erosion by water. Ecological Indicators https://doi.org/10.1016/i.ecolind.2017.05.035

- ten Brink P, Kettunen M, Watkins E (2017) Expert Group on Green and Circular Economy in the Outermost Regions: Final Report. For DG Regional and Urban Policy, European Commission., 30 pp.

- Thiault L, Collin A, Chlous F, Gelcich S, Claudet J (2017) Combining participatory and socioeconomic approaches to map fishing effort in small-scale fisheries. PLOS ONE 12 (5): e0176862. https://doi.org/10.1371/journal.pone.0176862

- Thomas C, Williams S, Cameron A, Green R, Bakkenes M, Beaumont L, Collingham Y, Erasmus BN, de Siqueira MF, Grainger A, Hannah L, Hughes L, Huntley B, van Jaarsveld A, Midgley G, Miles L, Ortega-Huerta M, Peterson AT, Phillips O (2004) Biodiversity conservation: Uncertainty in predictions of extinction risk/Effects of changes 
in climate and land use/Climate change and extinction risk (reply). Nature 430 (6995): . https://doi.org/10.1038/nature02719

- $\quad$ Tieskens KF, Schep SW, van Beukering PJH, van Beek IJM, Wolfs EM (2014) Mapping the economic value of ecosystems on St Eustatius. IVM Institute for Environmental Studies

- $\quad$ UK Government (2014) UK Overseas Territories Biodiversity Strategy. UK Government Activity. Foreign \& Commonwealth Office, Department for Environment, Food \& rural Affairs, Department for International Development

- UK NEA (2011) The UK National Ecosystem Assessment: Synthesis of the Key Findings. UNEP-WCMC, Cambridge.

- $\quad$ UNEP, PAP/RAC. (2009) Sustainable coastal tourism—An integrated planning and management approach. UNEP, Paris.

- $\quad$ Unsworth RK, Jones BL, Cullen-Unsworth L, L.M N (2017) How hurricanes such as Irma and Maria can devastate the Caribbean marine environment. the Conversation UK, 25.09.2017.

- Upson R, McAdam J, Clubbe C (2016) Climate Change Risk Assessment for Plants and Soils of the Falkland Islands and the Services they provide. Royal Botanic Gardens Kew and UK Falkland Islands Trust https://doi.org/10.13140/RG.2.2.15660.67203

- $\quad$ van Beukering P, Brouwer R, Schep S, Wolfs E, Brander L, Ebanks-Petrie G, Austin T (2014) The impact of invasive species on tourism. Wolfs Company

- $\quad$ van der Lely JA, van Beukering P,, Muresan L., Zambrano Cortes D,, Wolfs E,, Schep S (2013) The total economic value of nature on Bonaire. IVM Institute for Environmental Studies, Amsterdam.

- van Zanten B, van Beukering PH, Wagtendonk A (2014) Coastal protection by coral reefs: A framework for spatial assessment and economic valuation. Ocean \& Coastal Management 96: 94-103. https://doi.org/10.1016/j.ocecoaman.2014.05.001

- Verweij P, Debrot D, Meesters E (2015) Identifying indicators to report on the status and trends of biodiversity for the Dutch Caribbean; Indicators, monitoring and assessment methods and capacity estimates. Indicators, monitoring and assessment methods and capacityestimates. 2544. Alterra Wageningen UR (University \& Research, Wageningen.

- Vila M, Hulme PE (Eds) (2017) Impact of Biological Invasions on Ecosystem Services. Invading Nature - Springer Series in Invasion Ecology, 12. Springer, 354 pp. [ISBN 978-3-319-45121-3]

- Vilà M, Espinar JL, Hejda M, Hulme PE, Jarošík V, Maron JL, Pergl J, Schaffner U, Sun Y, Pyšek P (2011) Ecological impacts of invasive alien plants: a meta-analysis of their effects on species, communities and ecosystems. Ecology Letters 14 (7): 702-708. https://doi.org/10.1111/j.1461-0248.2011.01628.x

- Villamagna A, Angermeier P, Bennett E (2013) Capacity, pressure, demand, and flow: A conceptual framework for analyzing ecosystem service provision and delivery. Ecological Complexity 15: 114-121. https://doi.org/10.1016/j.ecocom.2013.07.004

- Waite R, Kushner B, Jungwiwattanaporn M, Gray E, Burke L (2015) Use of coastal economic valuation in decision making in the Caribbean: Enabling conditions and lessons learned. Ecosystem Services 11: 45-55. https://doi.org/10.1016/ j.ecoser.2014.07.010

- Wong PP (1993) Tourism vs Environment. The case for coastal areas. Springer Science \& Business Media [ISBN 978-94-011-2068-5] 
- Wong PP, Moro D, Rhonell J (2005) Island Ecosystems. Millennium Ecosystem Assessment: Ecosystems and Human Well-Being. current State and Trends.

- Worm B, Barbier EB, Beaumont N, Duffy JE, Folke C, Halpern BS, Jackson JBC, Lotze HK, Micheli F, Palumbi SR, Sala E, Selkoe KA, Stachowicz JJ, Watson R (2006) Impacts of Biodiversity Loss on Ocean Ecosystem Services. Science 314 (5800): 787-790. https://doi.org/10.1126/science.1132294

- Yam R, Huang K, Hsieh H, Lin H, Huang S (2015) An Ecosystem-Service Approach to Evaluate the Role of Non-Native Species in Urbanized Wetlands. International Journal of Environmental Research and Public Health 12 (4): 3926-3943. https:// doi.org/10.3390/ijerph120403926

\section{Supplementary materials}

Suppl. material 1: Regional Overview: Mapping and Assessment of Ecosystem Services in the Polar and South Polar EU Overseas Countries and Territories doi

Authors: Sieber et al. 2018

Data type: Map

Filename: B_SouthPolar_pie.jpg - Download file $(775.64 \mathrm{~kb})$

Suppl. material 2: Regional Overview: Mapping and Assessment of Ecosystem Services in the Macaronesian EU Outermost Regions doi

Authors: Sieber et al. 2018

Data type: Map

Brief description: all studies were conducted between 1991 and 2017 .

Filename: C_Macaronesia_pie_adjusted.jpg - Download file (513.26 kb)

Suppl. material 3: Regional Overview: Mapping and Assessment of Ecosystem Services in the Caribbean EU Outermost Regions and Overseas Countries and Territories doi

Authors: Sieber et al. 2018

Data type: Map

Filename: D_Caribbean_pie_adjusted.jpg - Download file (684.44 kb)

Suppl. material 4: Regional Overview: Mapping and Assessment of Ecosystem Services in the Amazonian EU Outermost Region doi

Authors: Sieber et al. 2018

Data type: Map

Filename: E_Amazonia_pie_adjusted.jpg - Download file (464.18 kb)

Suppl. material 5: Regional Overview: Mapping and Assessment of Ecosystem Services in the South Atlantic EU Overseas Countries and Territories doi

Authors: Sieber et al. 2018

Data type: Map

Filename: F_South_Atlantic_pie_adjusted.jpg - Download file $(620.70 \mathrm{~kb})$ 
Suppl. material 6: Regional Overview: Mapping and Assessment of Ecosystem Services in the Indian Ocean EU Outermost Regions and Overseas Countries and Territories doi

Authors: Sieber et al. 2018

Data type: Map

Filename: G_Indian_ocean_pie.jpg - ownload file $(566.57$ kb)

Suppl. material 7: Regional Overview: Mapping and Assessment of Ecosystem Services in the Pacific EU Overseas Countries and Territories doi

Authors: Sieber et al. 2018

Data type: Map

Filename: H_Pacific_pie.jpg - Download file $(640.25 \mathrm{~kb})$

Suppl. material 8: Appendix of included literature doi

Authors: Sieber et al. 2018

Data type: Literature List

Filename: 2018-05-14 Appendix Literature List_alpabetical_order.docx - Download file (70.54 kb)

\section{Endnotes}

\$ittp://biodiversity.europa.eu/maes

2tp://www.esmeralda-project.eu/

\$itp://cices.eu/

\$Atp://ec.europa.eu/environment/nature/biodiversity/best/regions/index en.htm

\$. 5 tp://www.netbiomecsa.netbiome.eu/np4/home.html

Ftps://biodiversity.europa.eu/

\$7tp://esp-mapping.net/Home/

\%tps://www.oppla.eu/case-studies

îtp://www.teebweb.org/

*ẹg. Caribbean (http://campam.gcfi.org/CaribbeanMPA/CaribbeanMPA.php) 